\title{
Pelatihan Blended Learning Melalui Aplikasi Mobile Bagi Guru SMP pada Masa Pandemi Covid-19
}

\author{
Muhammad Taufik Hidayat $^{1^{*}}$, Teuku Junaidi², Desy Irafadillah Effendi ${ }^{3}$ iD \\ ${ }^{1,2,3}$ Prodi Pendidikan Bahasa Indonesia, Universitas Samudra, Langsa-Aceh, Indonesia \\ *Corresponding author: muhammadtaufik89@unsam.ac.id
}

\begin{abstract}
Program pengabdian masyarakat ini bertujuan memberikan pelatihan blended learning melalui aplikasi mobile bagi guru SMP. Peserta pengabdian adalah guru-guru pada SMP yang berjumlah 35 orang guru. Kegiatan PKM ini dilakukan dengan memberikan teori terkait pembelajaran blended learning, pelatihan menggunakan aplikasi google classroom, dan pelatihan menggunakan aplikasi zoom meeting berbasis mobile handphone. Metode pelaksanaan pengabdian akan dilakukan dengan tiga tahap, yaitu tahap persiapan, tahap pelatihan menggunakan blended learning melalui aplikasi mobile; terakhir, tahap monitoring dan evaluasi. Hasil yang diperoleh adalah (1) hanya $40 \%$ guru yang menerapkan pembelajaran daring, (2) pengunaan modul pelatihan blended learning sangat penting selama pelatihan berlangsung, (3) pelaksanaan pelatihan berjalan dengan baik dan para guru mampu mengaplikasikan zoom meeting dan google classroom yang ada di handphone dan laptop mereka secara baik, (4) permintaan tindaklanjut dari kegiatan pelatihan ini.
\end{abstract}

Keywords: Pelatihan, Blended Learning, Aplikasi Mobile, Guru SMP

\section{Abstract}

This community service program aims to provide blended learning training through a mobile application for teachers of SMP. The community service participants are teachers at SMP totaling 35 teachers. This PKM activity is carried out by providing theories related to blended learning, training using the google classroom application, and training using the zoom meeting application based on mobile phones. The method of implementing the service will be carried out in three stages, namely the preparation stage, the training stage using blended learning through a mobile application; lastly, the monitoring and evaluation stage. The results obtained are (1) only $40 \%$ of teachers are implementing online learning, (2) the use of blended learning training modules is very important during the training, (3) the training is running well and the teachers are able to apply the existing zoom meetings and google classrooms. on their cellphones and laptops properly, (4) a follow-up request from this training activity.

Keywords: Training, Blended Learning, Mobile Applications, Junior High School Teachers

\section{Introduction}

Dunia sedang dihebohkan dengan hadirnya virus covid-19. Wabah corona virus telah melanda 215 negara di dunia, yang mengakibatkan perubahan tatanan berbagai sector pada kehidupan manusia (Chang et al., 2020; Wong et al., 2020). Salah satu bidang yang mengalami perubahan adalah bidang pendidikan, yang mana saat ini proses pembelajaran dilakukan secara daring yang awalnya pembelajaran dilaksanakan secara tatap muka (Anugrahana, 2020). Pembelajaran blended learning adalah salah satu solusi untuk pembelajaran di masa pandemi ini. Blended learning adalah suatu kegiatan pembelajaran yang mengombinasikan kegiatan tatap muka di kelas dengan kegiatan belajar menggunakan

$\begin{array}{lll}\text { History: } & & \text { Publisher: Undiksha Press } \\ \text { Received } & \text { : 10 Juni } 2020 & \text { Licensed: This work is licensed under } \\ \text { Revised } & : \text { 18 Juli } 2020 & \text { a Creative Commons Attribution 3.0 License } \\ \text { Accepted } & : \text { 15 Juli } 2020 & \text { CC OP OP } \\ \text { Published } & : \text { : } 01 \text { Agustus } 2020 & \end{array}$


media internet, (Ahmad et al., 2020; Fitriana, 2017; Ningsih et al., 2017). Pembelajaran blended learning dapat meningkatkan self-regulated siswa dan pada akhirnya dapat meningkatkan hasil belajar kognitif siswa (Usman, 2019; Fandianta, 2013).

Penelitian yang dilakukan oleh (Abdullah, 2018) yang menyatakan bahwa model pembelajaran blended learning dapat meningkatkan efektivitas dalam pembelajaran. Penelitian yang dilakukan oleh (Heru \& Yuliani, 2020) mengembangkan model pembelajaran e-learning berbasis web dengan prinsip e-pedagogy dalam meningkatkan hasil belajar dan hasilnya menunjukkan bahwa pembelajaran ini berdampak pada motivasi dan semangat siswa dalam belajar dan mencari serta menemukan dan mengajarkan siswa cara berpikir kritis dan logis. Pembelajaran blended learning akan sesuai dengan peruntukannya, jika dipersiapkan atau didukung oleh komponen-komponen pembelajaran.

Namun, permasalahan yang terjadi saat ini adalah minimnya pengetahuan guru pada saat mengoperasikan aplikasi blended learning contohnya adalah google class room dan media daring lainnya. Padahal sebagai upaya menghadapi society 4.0 manusia sudah mengenal dan memanfaatkan teknologi informasi dan komunikasi dalam pembelajaran (Irawan, 2020). Pelatihan Blended Learning pada guru harus ditingkatkan. Daya tarik pembelajaran blended learning di era 21 ini memang besar peranannya untuk mempermudah siswa dalam melakukan proses pembelajaran dimana saja dan kapan pun (Wardani, Deklara Nanindya, 2018). Hal ini juga ditemukan pada salah satu sekolah menengah pertama. Masalah utama adalah siswa ataupun guru masih minim penguasaan teknologi dan masih menggunakan pembelajaran secara tradisional. Permasalahan tersebut lebih khusus dihadapi oleh guru dan siswa pada SMP Negeri 4 Langsa. Berdasarkan observasi dan wawancara di SMP Negeri 4 Langsa solusi yang ditawarkan kepada mitra adalah melakukan pelatihan dan pendampingan serta mengaplikasikan rancangan pembelajaran mata pelajaran agar kualitas pembelajaran meningkat terhadap perkembangan ilmu pengetahuan dan teknologi. SMPN 4 Langsa adalah salah satu sekolah yang siap menerima pelatihan dan pendampingan blended learning karena memiliki fasilitas teknologi cukup melakukan blended learning. Selain itu, hubungan siswa di SMPN 4 Langsa dengan teknologi akan membuat siswa gembira, apalagi ada hubungannya dengan internet. Guru SMPN 4 juga konsisten dalam menyampaikan bahan ajar dan selalu update. Atas dasar analisis situasi tersebut, SMPN 4 Langsa dirasa siap menerima pelatihan dan pendampingan blended learning. Sudah sewajarnya kita sebagai guru yang hidup di zaman digital ini menambah keterampilan di salah satu bidang teknologi yang dapat digunakan untuk menyukseskan kegiatan belajar mengajar siswa.

Penelitian yang dilakukan oleh (Mayasari et al., 2019; Suhartono, 2017) juga menyatakan pelatihan blended learning merupakan suatu usaha yang kreatif dan efektif dapat ditinjau berdasarkan kualitas hasil pembelajaran siswa baik berupa hasil pemikiran yang dapat disampaikan kembali oleh siswa melalui pembicaraan langsung maupun tertulis. Berdasarkan penelitian tersebut maka dapat disimpulkan bahwa model pelatihan blended learning adalah sebuah kemudahan pembelajaran yang menggabungkan berbagai cara penyampaian, model pengajaran, dan gaya pembelajaran, memperkenalkan berbagai pilihan media dialog antara fasilitator dengan orang yang mendapat pengajaran sehingga membuat siswa aktif dalam belajar.

Berdasarkan uraian yang telah dipaparkan, urgensi atau pentingnya pelatihan ini bertujuan memberikan Pelatihan Blended Learning Melalui Aplikasi Mobile bagi Guru SMPN 4 Langsa pada Masa Pandemi Covid-19. Metode ini sangat efektif dalam menambah efisiensi serta peningkatan diskusi atau meninjau kembali informasi di luar ruang kelas. Keuntungan dari belajar blended learning, yaitu: 1) hemat biaya; 2) guru dapat secara online ataupun tatap wajah memberi materi secara interaktif; 3) memberikan fleksibilitas pada saat menentukan waktu dan tempat untuk mengakses pelajaran; 4) serta memberikan kesempatan bagi siswa secara mandiri untuk memegang kendali atas keberhasilan belajarnya sendiri. 
Tujuan dari kegiatan pelatihan ini adalah menyediakan peluang yang praktis realistis bagi guru dan pendidik untuk pembelajaran secara mandiri, bermanfaat, dan terus berkembang sehingga berdampak positif terhadap hasil belajar siswa. Dengan pelatihan blended learning ini diharapkan dapat meningkatkan dan memanfaatkan penggunaan teknologi internet secara optimal dalam pengembangan pembelajaran dan membantu pendidik untuk berkembang lebih baik di dalam proses belajar, sesuai dengan gaya belajar dan preferensi dalam belajar

\section{Materials and Methods}

Peserta kegiatan pengabdian masyarakat ini adalah guru-guru SMP Negeri 4 Langsa yang berjumlah 35 orang guru. Agar kegiatan pengabdian masyarakat ini berjalanan dengan lancar, beberapa mahasiswa turut membantu dalam proses kegiatan. Pelaksanaan kegiatan ini dilakukan dalam tiga tahap. Tahap pertama, yaitu tahap persiapan yang artinya pada tahap ini dilakukan survei awal pendahuluan untuk melihat kondisi sekolah mengenai aktivitas pembelajaran yang berlangsung selama masa pandemi ini. Selanjutnya dilakukan observasi guna meninjau ketersediaan sarana dan prasarana yang ada di lokasi pengabdian. Pada tahapan ini juga harus dilakukan persiapan untuk pengumpulan alat dan bahan yang pasti dibutuhkan selama pelaksanaan kegiatan.

Tahap kedua yaitu pelatihan blended learning melalui aplikasi mobile. Tahap ini dimulai dengan memberikan materi awal. Metode yang digunakan adalah metode demonstrasi, yaitu metode yang digunakan untuk menunjukkan tentang cara melakukan atau mengerjakan sesuatu. Pada tahap ini, para peserta pelatihan melakukan tanya jawab seputaran pengaplikasian zoom meeting dan google classroom. Setelah materi selesai diberikan, para peserta langsung mempraktikkan penggunaan zoom meeting dan google classroom yang terlebih dahulu telah diinstal di laptop maupun handphone masing-masing peserta. Dalam mempraktikkan penggunaan zoom dan google classroom, para peserta pelatihan dibantu oleh mahasiswa yang ikut berpartisipasi dalam kegiatan pengabdian masyarakat ini.

Tahap terakhir yaitu tahap monitoring dan evaluasi artinya pada tahap ini akan dilaksanakan evaluasi atas pencapaian hasil kegiatan yang telah dilaksanakan oleh guru SMPN 4 Langsa. Masukan dan perbaikan terhadap proses pelatihan lebih lanjut dapat dilakukan pada tahap ini. Hal tersebut juga memberikan pengalaman belajar mengajar baru bagi guru dan siswa sehingga proses belajar dan mengajar akan dapat lebih bervariatif dan inovatif.

\section{Results and Discussion}

\section{Perencanaan: Identifikasi Pengetahuan Guru Terhadap Penggunaan Google Classroom}

Pengetahuan guru terhadap google classroom masih tergolong rendah. Hanya $40 \%$ dari 35 orang guru yang mahir dan terampil menggunakan blended learning dalam pembelajaran. Persentase Pengetahuan Guru terhadap Blended Learning dalam Pembelajaran dapat dilihat pada Gambar 1.

Berdasarkan hasil identifikasi, ternyata guru SMP Negeri 4 Langsa belum mahir menggunakan aplikasi blended learning. Dari 35 orang guru hanya $60 \%$ yang mahir dan terampil menggunakan aplikasi blended learning dalam pembelajaran. Permasalahan tersebut muncul karena keterbatasan sarana dan prasarana teknologi di lingkungan sekolah. Kemudian, dari hasil wawancara yang dilakukan tim pengabdi Unsam, pihak sekolah juga membatasi telepon pintar (handphone) dengan alasan mengganggu konsentrasi belajar. Setelah pelatihan ini dilakukan. Tim pengabdi melakukan pendampingan dan monitoring ke SMP Negeri 4 Langsa guna memperoleh data. Pada masa pandemi covid-19 ini guru dan siswa sudah terbiasa dengan aplikasi blended learning karena diterapkannya work from home 
(WFH). Semua pelajaran sudah tersistem semuanya dalam perangkat, siswa tinggal mendownload dan mengerjakan tugas yang ada di handphone masing-masing.

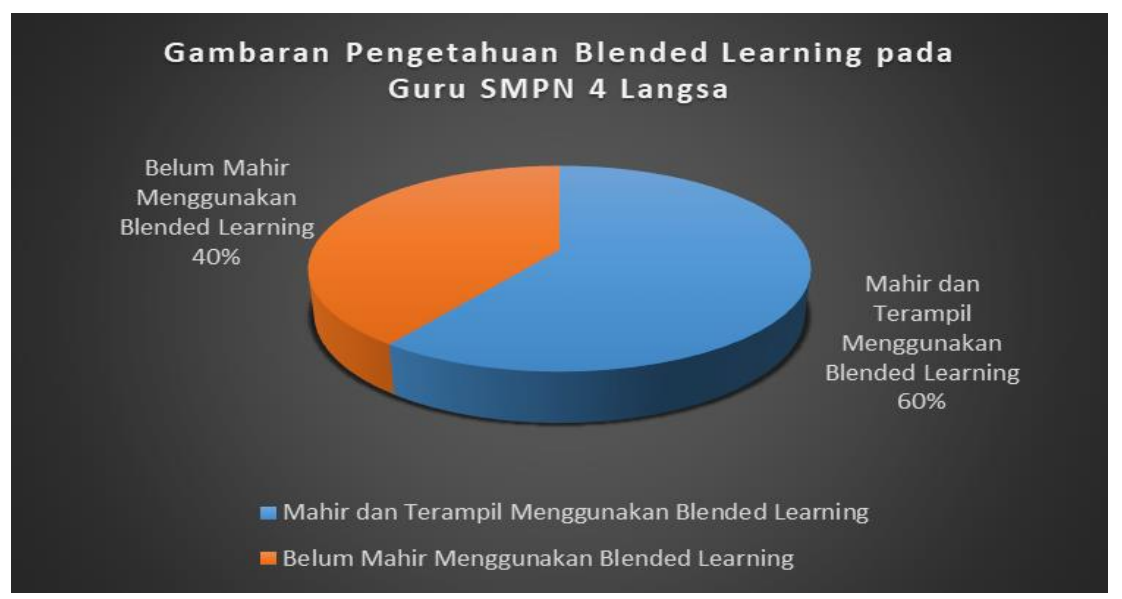

Gambar 1. Persentase Pengetahuan Guru terhadap Blended Learning dalam Pembelajaran

\section{Perencanaan: Penyediaan Modul Pelatihan}

Berbagai upaya dalam tercapainya suatu kegiatan pelatihan tentu sudah dipersiapkan dengan baik oleh tim pengabdi Universitas Samudra. Salah satunya penyediaan modul pengaplikasian zoom meeting dan google classroom yang telah dikemas dalam bentuk modul dan disajikan juga dalam bentuk PPT agar mudah guru memahaminya. Adapun materi yang diberikan mengenai pengaplikasian zoom meeting, yaitu sebagai berikut. (1) Cara mengunduh zoom meeting di handphone ataupun laptop; (2) Cara membuat akun; (3) Cara mengubah nama pengguna zoom meeting; (4) Cara menjadi host dan membuat ruangan di zoom meeting; (5) Mengundang peserta melalui email atau menyalin link yang tertera; (6) Cara mematikan suara seluruh peserta; (7) Cara melihat peserta yang bergabung. Dan (8) Cara mengakhiri meeting untuk semua atau meninggalkan meeting. Sedangkan materi google classroom yang diberikan yaitu sebagai berikut. (1) Cara mengunduh google classroom pada handphone maupun laptop peserta, (2) Cara login ke website google classroom; (3) Cara membuat kelas baru; (4) Cara menambahkan peserta ke dalam kelas; (5) Cara mengisi konten dengan materi PPT, docx, pdf, dll; dan (6) Cara memberikan tugas untuk siswa. Modul Pelatihan dapat dilihat pada Gambar 2.

Modul pelatihan tersebut diberikan kepada Guru SMP Negeri 4 Langsa sejumlah 35 eksemplar dalam bentuk cetak (hardcopy). Sedangkan modul dalam bentuk non cetak (soft copy) diberikan link google drive kegunaannya adalah seluruh guru bisa mendownload kembali bahan tersebut bila diperlukan. Penyusunan modul pelatihan akan membantu instruktur atau pemateri dalam menyampaikan materi pelatihan. Modul pelatihan yang disusun bisa membantu peserta untuk belajar mandiri jika dibutuhkan diluar waktu pelatihan (Sumini, 2018). 

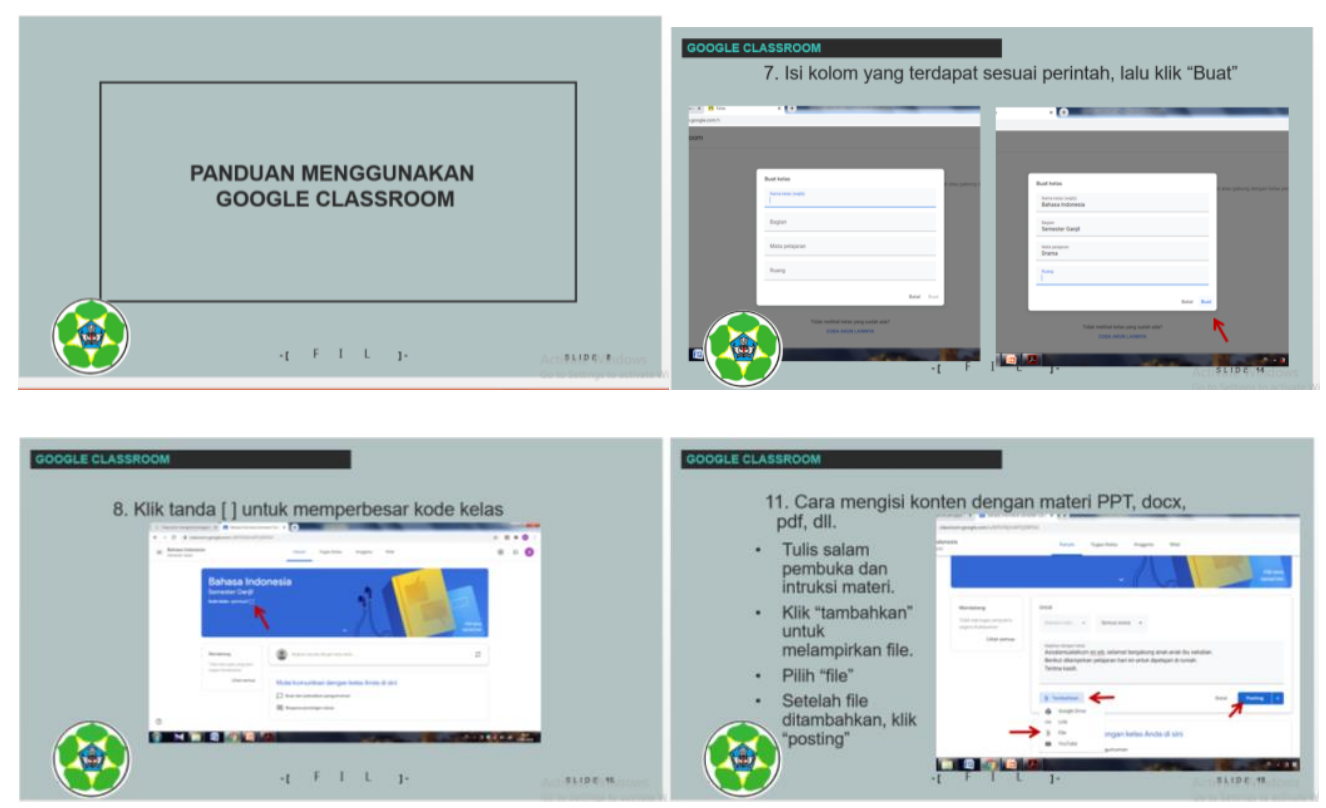

Gambar 2. Beberapa Gambar Potongan dari Modul Pelatihan

\section{Pelaksanaan Pelatihan Blended Learning}

Pengabdian masyarakat ini dilakukan pada tanggal 28 Juli 2020 di SMP Negeri 4 Kota Langsa. Tim pengabdian ini melibatkan 3 orang dosen dan dibantu 5 orang mahasiswa dari kampus Universitas Samudra Langsa. Lokasi pelatihan ini dilakukan di laboratorium IPA SMP Negeri 4 Kota Langsa. Jumlah peserta yang hadir pada pelatihan ini sebanyak 35 orang. Kegiatan ini dibuka langsung oleh salah satu dosen yang terlibat dalam penelitian. Setelah kegiatan dibuka, para tim pengabdian mulai memberikan materi awal yaitu mengenai zoom meeting. Para peserta diarahkan terlebih dahulu untuk mengunduh aplikasi zoom meeting di laptop maupun handphone masing-masing. Setelah aplikasi zoom meeting berhasil diunduh, mereka menyimak dengan seksama materi mengenai pengaplikasian zoom meeting ini. Selama materi disampaikan, peserta dipersilahkan bertanya jika ada hal yang kurang dimengerti dan akan dijawab langsung oleh pemateri. Setelah materi selesai disampaikan, para peserta langsung mempraktikkan penggunaan zoom meeting dibantu oleh mahasiswa yang ikut berpartisipasi dalam kegiatan pengabdian ini. Pertama-tama mereka bergabung ke rapat yang dibuat oleh pemateri. Selanjutnya para guru mencoba membuat rapat sendiri dan saling mengundang temannya. Kendala pada pengaplikasian zoom meeting ini adalah ketika membuat akun. Namun kendala tersebut berhasil dilalui karena bantuan dari tim pengabdian dan juga mahasiswa yang telah memahami penggunaan aplikasi ini. Berikut adalah dokumentasi dari pelatihan blended learning. Pelaksanaan Pelatihan Blended Learning pada Guru SMPN 4 Langsa dapat dilihat pada Gambar 3.

Penyampaian materi dilakukan secara sistematis oleh Tim Pengabdi Universitas Samudra. Diawali dengan pengamalan aplikasi zoom meeting serta praktik penggunaannya dan pengenalan google classroom. Setelah para peserta memahami penggunaan zoom meeting, selanjutnya diberikan materi mengenai penggunaan google classroom. Peserta terlebih dahulu diarahkan untuk mengunduh aplikasi google classroom di handphone maupun laptop mereka. Sama halnya ketika penyampaian materi mengenai zoom meeting, selama penyampaian materi google classroom peserta juga dipersilahkan bertanya jika ada hal yang kurang dimengerti agar bisa langsung dijawab oleh pemateri. Setelah materi selesai disampaikan, para peserta langsung mempraktikkan penggunaan google classroom ini. 
Mereka mencoba bergabung ke kelas yang telah dibuat oleh pemateri dan menjawab tugas yang diberikan di kelas tersebut. Setelah itu mereka langsung mencoba membuat kelas baru dan mencoba memasukan tugas ke dalam kelasnya. Tidak ada kendala yang dihadapi ketika mengaplikasikan google classroom karena aplikasi ini lebih mudah dari pada zoom meeting dan penjelasan yang disampaikan pemateri sangat mudah untuk dipahami.
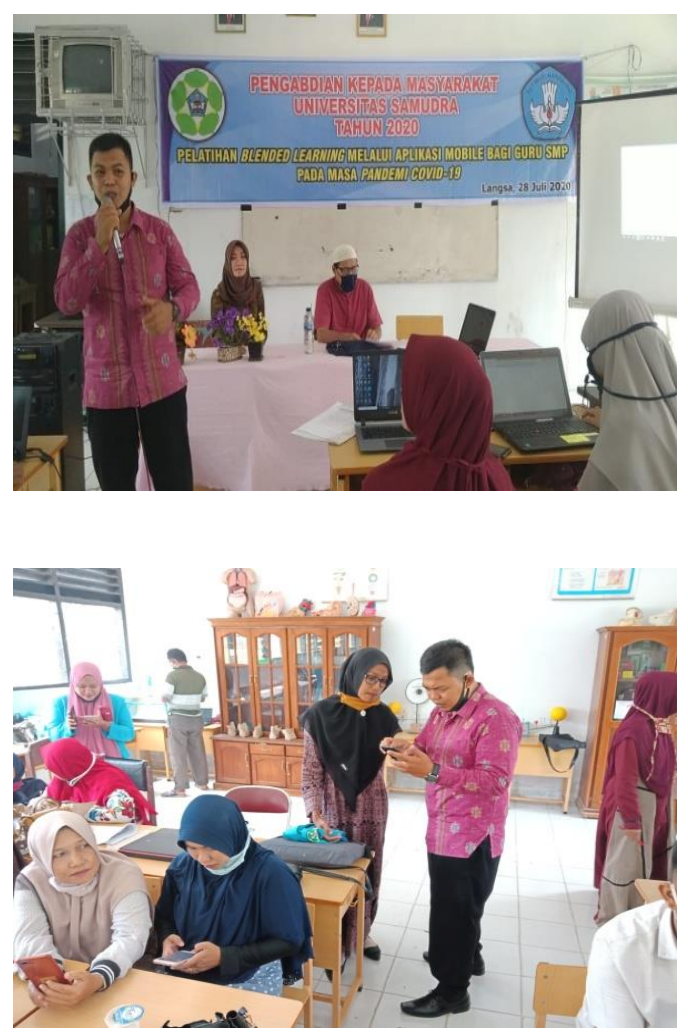
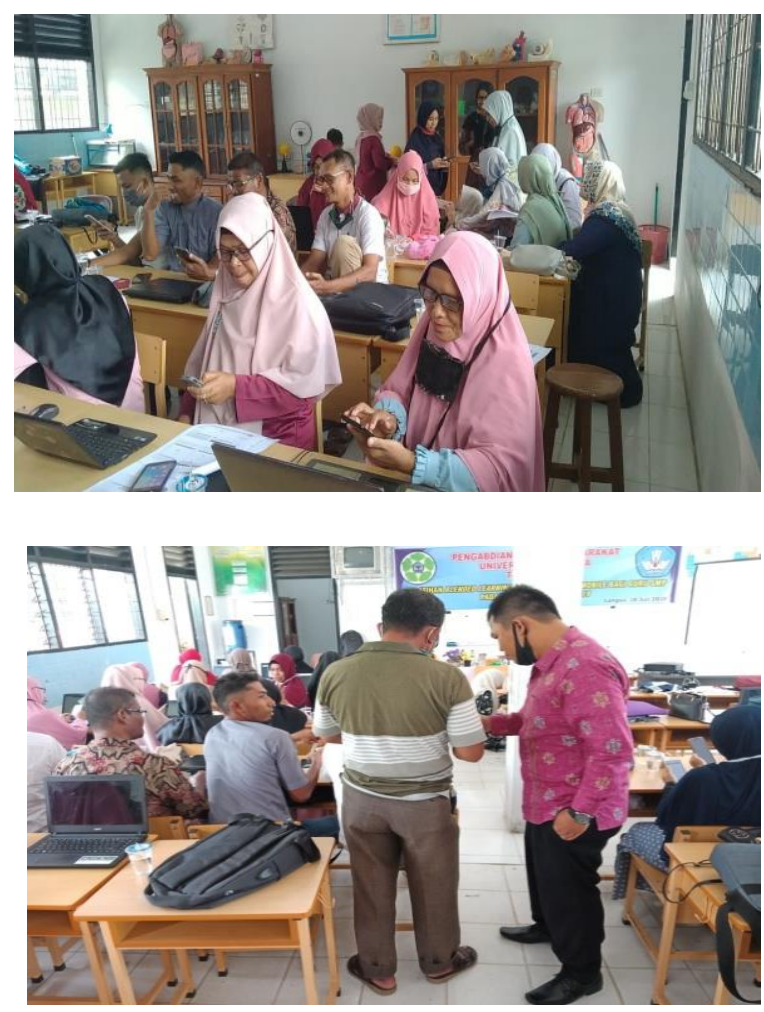

Gambar 3. Pelaksanaan Pelatihan Blended Learning pada Guru SMPN 4 Langsa

\section{Evaluasi}

Dari pelatihan yang telah diberikan, guru merasa sangat terbantu karena dalam masa pandemi seperti ini guru dituntut untuk melakukan proses pembelajaran secara daring. Dengan adanya pelatihan guru menjadi mampu untuk mengaplikasikan zoom meeting dan juga google classroom. Zoom meeting berguna bagi guru jika ingin menyampaikan materi secara langsung kepada siswa dan aplikasi ini juga mampu menampung hingga 100 peserta sehingga seluruh siswa yang akan diberikan materi dapat bergabung. Di aplikasi ini juga guru bisa melakukan interaksi kepada para siswanya seperti mengajukan pertanyaan ataupun menjawab pertanyaan yang diberikan siswa. Sedangkan aplikasi google classroom berguna bagi guru jika ingin memberikan tugas kepada siswa. Guru hanya perlu mengirimkan tugas ke kelas yang sudah ia buat di aplikasi ini dan para siswa memberikan jawaban sesuai tenggat waktu yang telah diberikan. Kedua aplikasi ini mampu membuat proses pembelajaran menjadi efektif dan efisien.

Pertama, pelatihan blended learning merupakan salah satu aplikasi yang dapat membantu guru mewujudkan komunikasi yang efektif antara siswa dan guru menggunakan google classroom (Mayasari et al., 2019). Hal ini didukung oleh (Nugraha et al., 2019) yang menyatakan bahwa seiring perkembangan zaman proses kegiatan belajar mengajar di kelas memiliki banyak tantangan dan tuntutan. Semakin banyaknya jalur informasi yang dapat 
diakses oleh siswa semakin baik dalam proses pembelajaran sehingga siswa tambah menambah wawasan dan informasi terkait dengan pembelajaran. Oleh karena itu, guru harus meng-upgrade dan mengimbangi materi pembelajaran yang didapatkan dengan mencari berbagai informasi tambahan. Pelatihan Blended Learning Melalui Aplikasi Mobile bagi Guru SMPN 4 Langsa pada Masa Pandemi Covid-19 dapat dimanfaatkan oleh guru untuk salah satu media dalam menerapkan strategi pembelajaran daring. Kelebihan pembelajaran google class room ini adalah media ini tidak hanya dapat diakses oleh laptop saja, namun media google classroom dan media daring lainnya dapat diakses dalam aplikasi android sehingga sangat efektif dan efisien dalam pembelajaran. Hal ini bisa mempermudah guru dalam memantau kinerja dan interaksi antara guru dan siswa melalui handphone atau android.

Kedua, pelatihan blended learning pada SMP Negeri 4 Langsa telah dikembangkan melalui alur yang sistematis. Penerapan blended learning dapat dijadikan sebagai strategi pengorganisasian pengajaran, penyampaian pengajaran dan kualitas pengajaran karena blended learning mampu untuk mengakomodasi perkembangan teknologi yang luas tanpa harus meninggalkan pembelajaran tatap muka (face-to-face) (Wardani, Deklara Nanindya, 2018). Pada proses pelatihan blended learning ini guru difokuskan untuk mempelajari dan pengaplikasian zoom meeting, google classroom, dan materi google form untuk memudahkan guru dalam proses pembelajaran berlangsung pada masa pandemic ini. Pelatihan Blended Learning Melalui Aplikasi Mobile bagi Guru SMPN 4 Langsa dilakukan pada satu ruangan kelas (aula) yang memiliki jaringan internet yang kuat dan memadai sehingga guru dapat praktik menggunakan aplikasi blended learning dengan menggunakan handphone, android, ataupun dengan laptop. Pelatihan ini juga diberikan modul penggunaan zoom meeting, google classroom, dan materi google form sesuai dengan karakteristik suatu pelatihan yang menitikberatkan pada pengembangan keterampilan peserta. Kebutuhan akan pelatihan offline dan online memerlukan modul. Untuk mewujudkan sebuah modul sendiri, masih diperlukan penjelasan lebih rinci mengenai komponen modul yang baik (Pustadi, 2019).

Ketiga, pelaksanaan pelatihan blended learning berjalan dengan baik dan para guru mampu mengaplikasikan zoom meeting, google classroom, dan google form yang ada di handphone dan laptop mereka secara baik. Pelatihan blended learning memang sangat tepat jika diterapkan di tengah covid-19 ini. Pelatihan blended learning berpeluang menggeser paradigma pembelajaran yang berpusat pada pendidik, menuju paradigma baru yang berpusat pada siswa. Model ini juga memungkinkan berpeluang peningkatan interaksi antar siswa dan guru, serta berpeluang terjadi konvergensi antar berbagai metode, media sumber belajar, dan lingkungan belajar yang relevan (Isa, 2015). Dalam kegiatan pelatihan, tim pengabdi bertanya jawab kepada peserta pelatihan sudah pernah atau belum dilakukan pelatihan yang berhubungan dengan blended learning. Ternyata, baru kali ini peserta (guru) mendapatkan pelatihan dan praktik penggunaan blended learning hingga tuntas sampai menggunakan aplikasinya di handphone atau android masing-masing guru. Suasana pertanyaan dan respons dari guru terhadap pelatihan ini menjadi pelatihan menjadi aktif. Kemudian, di penghujung acara para guru SMPN 4 Langsa permintaan tindak lanjut dari kegiatan pelatihan ini.

Temuan dalam pelatihan ini adalah setiap kegiatan pelatihan ini sudah berdasarkan sintak blended learning yaitu (Seeking of information) pencarian informasi dari berbagai sumber informasi yang tersedia secara online maupun offline. Kemudian, (Acquisition of information) yaitu menemukan, memahami, serta mengonfrontasikan dengan ide atau gagasan yang telah ada dalam pikiran kemudian menginterprestasikan informasi/pengetahuan dari berbagai sumber yang tersedia, dan (Synthesizing of knowledge) menginterpretasikan ide-ide dan hasil interpretasi menggunakan fasilitas online/offline (Hendarita, 2013). Sehingga dapat disimpulkan bahwa Pelatihan Blended Learning Melalui Aplikasi Mobile 
bagi Guru SMPN 4 Langsa pada Masa Pandemi Covid-19 berpengaruh positif bagi guru. Dengan adanya pelatihan ini aplikasi blended learning dapat digunakan oleh guru untuk meningkatkan hasil belajar dan menciptakan pembelajaran yang asyik dan menyenangkan sehingga siswa tidak merasa bosan pada saat proses pembelajaran berlangsung.

\section{Conclusion}

Kegiatan pengabdian masyarakat yang dilakukan dosen-dosen Universitas Samudra Langsa ini dikategorikan berhasil karena tujuan kegiatan ini telah tercapai dengan maksimal. Dari keseluruhan peserta, 90 persen telah mampu mengaplikasikan zoom meeting dan juga google classroom di handphone maupun laptop masing-masing. Mereka telah mampu menggunakan kedua aplikasi ini sebagai media pembelajaran dalam masa pandemi ini. Diharapkan dengan adanya pelatihan ini, para guru menjadi lebih semangat untuk memberikan ilmu kepada para siswanya. Para guru yang telah mengikuti pelatihan diharapkan dapat mengajarkan guru lainnya yang tidak dapat hadir dalam pelatihan ini agar seluruh guru dapat menggunakan kedua aplikasi ini untuk proses pembelajaran.

\section{References}

Abdullah, W. (2018). Model Blended Learning dalam Meningkatkan Efektifitas Pembelajaran. Fikrotuna, 7(1), 855-866. https://doi.org/10.32806/jf.v7i1.3169

Ahmad, Perwira Negara, H. R., Ibrahim, M., \& Etmy, D. (2020). Pelatihan Pembelajaran Daring (Google Classroom) bagi Guru MTs dan MI Nurul Yaqin Kelanjur. JPMB : Jurnal Pemberdayaan Masyarakat Berkarakter, 3(1), 66-79. https://doi.org/10.36765/jpmb.v3i1.224

Anugrahana, A. (2020). Hambatan, Solusi dan Harapan : Pembelajaran Daring Selama Masa Pandemi Covid-19 Oleh Guru Sekolah Dasar. Scholaria: Jurnal Pendidikan Dan Kebudayaan, 10(3), 282-289. https://ejournal.uksw.edu/scholaria/article/view/4033

Chang, T. Y., Hong, G., Paganelli, C., Phantumvanit, P., Chang, W. J., Shieh, Y. S., \& Hsu, M. L. (2020). Innovation of dental education during COVID-19 pandemic. Journal of Dental Sciences, 155. https://doi.org/10.1016/j.jds.2020.07.011

Fandianta, D. (2013). Meningkatkan Pengetahuan Mahasiswa dengan Memberikan Fleksibilitas Belajar Mengajar Melalui Metode Blended Learning. Jurnal Pendidikan Kedokteran Indonesia, 2(2), 1-8.

Fitriana, N. (2017). Mata Kuliah Pemisahan Kimia Materi Kromatografi Untuk Meningkatkan Kualitas Belajar. Journal of Educational Innovation, 4(1), 46-54. https://erudio.ub.ac.id/index.php/erudio/article/view/210/185

Hendarita, Y. (2013). Model Pembelajaran Blended Learning. Jurnal Teknologi, 1(1), 69-73. https://doi.org/10.11113/jt.v56.60

Heru, H., \& Yuliani, R. E. (2020). Pelatihan Pengembangan Bahan Ajar Multimedia Pembelajaran Interaktif Berbasis Pendekatan Saintifik Menggunakan Metode Blended Learning bagi Guru SMP/MTs Muhammadiyah Palembang. Jurnal Pengabdian Pada Masyarakat, 5(1), 35-44. https://doi.org/10.30653/002.202051.279

Irawan, E. (2020). Pelatihan Blended Learning sebagai Upaya Menghadapi Society 5.0. Aksiologiya: Jurnal Pengabdian Masyarakat, Vol 4, No., 181-189. http://dx.doi.org/10.30651/aks.v4i2.3499

Isa, Y. (2015). Pengembangan Model Blended Learning Mata Kuliah Perencanaan Teknologi Pembelajaran Teknologi Informasi dan Komunikasi. Jurnal Teknologi Pendidikan, 
17(2), 73-83. https://doi.org/10.21009/jtp.v17i2.10226

Ivone, F. M., Mukminatien, N., \& Tresnadewi, S. (2020). Blended Learning Untuk Penguatan Kompetensi. Jurnal Graha Pengabdian, 2, 18-26. http://journal2.um.ac.id/index.php/jgp/article/view/12159

Mayasari, F., Dwita, D., Jupendri, J., Jayus, J., Nazhifah, N., Hanafi, K., \& Putra, N. M. (2019). Pelatihan Komunikasi Efektif Media Pembelajaran Google Classroom Bagi Guru Man 2 Model Pekanbaru. Jurnal Pengabdian UntukMu NegeRI, 3(1), 18-23. https://doi.org/10.37859/jpumri.v3i1.1155

Ningsih, Y. L., Misdalina, M., \& Marhamah, M. (2017). Peningkatan Hasil Belajar dan Kemandirian Belajar Metode Statistika Melalui Pembelajaran Blended Learning. AlJabar: Jurnal Pendidikan Matematika, 155. https://doi.org/10.24042/ajpm.v8i2.1633

Nugraha, N. B., Sellyana, A., \& Suhaidi, M. (2019). Pelatihan E-Learning Pada Guru Sma It Plus Bazma Brilliant. 2(2), 127-132. https://doi.org/10.33330/jurdimas.v2i2.334

Pustadi, S. (2019). Pengembangan Modul Pelatihan Berbasis Blended Learning untuk Meningkatkan Keterampilan Inkuiri dan Scaffolding Guru Kimia. 22, 1-15.

Suhartono. (2017). Menggagas Penerapan Pendekatan Blended Learning Di Sekolah Dasar.

Usman, U. (2019). Komunikasi Pendidikan Berbasis Blended Learning Dalam Membentuk Kemandirian Belajar. Jurnal Jurnalisa, 4(1), 136-150. https://doi.org/10.24252/jurnalisa.v4i1.5626

Wardani, Deklara Nanindya, D. (2018). Daya Tarik Pembelajaran Di Era 21 Dengan, UsersHPDownloads2852-9931-1-PB.pdf. Jktp, 1(April), 13-18.

Wong, G. L. H., Wong, V. W. S., Thompson, A., Jia, J., Hou, J., Lesmana, C. R. A., Susilo, A., Tanaka, Y., Chan, W. K., Gane, E., Ong-Go, A. K., Lim, S. G., Ahn, S. H., Yu, M. L., Piratvisuth, T., \& Chan, H. L. Y. (2020). Management of patients with liver derangement during the COVID-19 pandemic: an Asia-Pacific position statement. The Lancet Gastroenterology and Hepatology, 5(8), 776-787. https://doi.org/10.1016/S2468-1253(20)30190-4 